\title{
Determining Position of the Evaporator in a Smart Classroom Concept Using CFD Method
}

\author{
Rosyida Permatasari* \\ Dept. Of Mechanical Engineering \\ Universitas Trisakti \\ Jakarta, Indonesia \\ rosyida@trisakti.ac.id \\ Sally Cahyati \\ Dept. Of Mechanical Engineering \\ Universitas Trisakti \\ Jakarta, Indonesia \\ sally@trisakti.ac.id
}

\author{
Muhammad Alwan Ridhoarto \\ Dept. Of Mechanical Engineering \\ Universitas Trisakti \\ Jakarta, Indonesia \\ muhalwanr@gmail.com \\ Martinus Bambang Susetyarto \\ Dept. Of Architecture \\ Universitas Trisakti \\ Jakarta, Indonesia \\ bambang.s@trisakti.ac.id
}

*Corresponding author: rosyida permatasari, rosyida@trisakti.ac.id

\begin{abstract}
Various, different evaporator placements in a room have produced different airflow patterns, temperature distribution, and airflow velocities. In this study, the average room temperature and airflow velocity measured at 27 points of the CFD simulation for 4 positions of the planned evaporator placements were compared to determine the most ideal position based on the comfortable temperature and the maximum airflow velocity pursuant to the SNI 03-6572-2001 recommendation. On Position 1, two evaporators were given to the west wall. Position 2, two evaporators were placed on the south wall. On Position 3, two evaporators were given to the north wall. Moreover, on Position 4, two evaporators were placed opposite to each other where an evaporator was placed on the south wall, and the other evaporator was placed on the north wall. An ANSYS Fluent software was employed to make the CFD simulation. Based on the results of the study, it was found out that Position 2 was the most ideal evaporator placement position since it met the comfortable temperature limit and has the highest number of airflow velocity points meeting the recommended maximum airflow velocity pursuant to the SNI 03-6572-2001 recommendation.
\end{abstract}

Keywords: Air Conditioner, Airflow, CFD Simulation, Evaporator Position.

\section{INTRODUCTION}

A Smart Classroom educational concept has begun to serve as an alternative concept in the learning and teaching activities. A combination of a digital technology and education is the concept of a Smart Classroom. It is expected that the application of a Smart Classroom will help enhance the productivity in the process of the learning and teaching activities [1][2].

Thermal comfort is a crucial factor impacting on the teaching and learning activities in a classroom. Moreover, a comfortable situation depends heavily on several climatic variables such as radiation due to the sun exposure, the humidity, the air temperature, and the wind speed around the building [3]. Geographically, Indonesia is located in the equatorial region, so Indonesia has an equatorial climate which is hot and humid. Therefore, Indonesia has a high temperature and a high humidity. This condition has resulted in a dependence on the use of an air conditioner (AC) in a classroom to achieve such a comfortable situation [4][5].

In a room, an installed air conditioner also serves as an effort made to increase the productivity of the learning and teaching activities. In a classroom, the presence of an installed air conditioner can be used to regulate the room temperature to provide a thermal comfort in order to increase the productivity in the learning and teaching activities [6].

In the split type of an air conditioner, the AC component is divided into two units, namely the indoor unit consisting of an air filter, an evaporator and a blower, an expansion valve and a control unit; and an outdoor unit consisting of a compressor, a condenser and a condenser fan. Moreover, both of the indoor unit and the outdoor unit employ 2 refrigerant channels; one channel is used to connect the evaporator to the compressor, and the other channel is used to connect the compressor and condenser to the expansion valve.

Moreover, it is also used to connect the power cable to the supply electric current and to the compressor and the condenser fan. A Split AC is suitable for any rooms requiring such a quiet ambience such as bedrooms, workspaces, classrooms, and libraries. Rasyid (2017) stated that several things could affect the performance of an AC, one of which was the position of the evaporator in a room [7][8].

Pursuant to SNI 03-6572-2001 meant to reach and maintain a comfortable situation, the airflow velocity falling 
over the head must not be higher than $0.25 \mathrm{~m} / \mathrm{s}$ and must be lower than $0.15 \mathrm{~m} / \mathrm{s}$. Moreover, the temperature limits are as follows [9]:

\section{Comfortable cool category $\left(20.5^{\circ} \mathrm{C}-22.8^{\circ} \mathrm{C}\right.$,}

2. Optimal comfort category $\left(22.8^{\circ} \mathrm{C}-25.8^{\circ} \mathrm{C}\right)$

3. Warm comfortable category $\left(25.8^{\circ} \mathrm{C}-27.1^{\circ} \mathrm{C}\right)$

Therefore, this study was aimed at making a simulation of an airflow pattern of the planned evaporator positions by employing a Computational Fluid Dynamics (CFD) method with variables and conditions obtained from the observational data and other various references. The simulation of an air flow pattern was aimed at predicting the distribution of the air flow and the temperature of the room and at determining an ideal position of the evaporator placement which will be implemented in the Smart Classroom concept on the Pusdiklat Building.

\section{ReseARCh Methodology}

The simulation of an air flow pattern coming out of the evaporator was made by employing an ANSYS Fluent 2020 $\mathrm{R} 1$ software based on various room characteristics such as the space dimensions, the physical properties of the air around the room, and the layout of the furniture and equipment having been determined to get the air temperature distribution in the Smart Classroom concept. The modelling to be made in the simulation would be as follows [5]:

- The air conditioning system in the room was properly functional.

- The dimensions and the angle of the evaporator air output were made the same for each of the positions.

- The Smart Classroom was completely closed with no holes or gaps.

- Constant (indoor) temperature.

- The equipment and the furniture were included in the simulation.

The dimensions ( 1 by w by h) Smart Classroom were 9.3 $\mathrm{m}$ by $8.9 \mathrm{~m}$ by $3 \mathrm{~m}$. The walls of the Smart Classroom had a masonry material with brick blocks and cement plaster with the heat transfer coefficient value amounting to 7,746 W/m2K and the free stream temperature on the west wall amounting to $302.85 \mathrm{~K}$ and $300 \mathrm{~K}$ on the other wall. There were concrete columns on each side of the walls with the heat transfer coefficient value amounting to $0.515 \mathrm{~W} / \mathrm{m} 2$. Moreover, there was also a window with a 10-mm-thick single sheet glass type with heat transfer coefficient value amounting to $5.74 \mathrm{~W} / \mathrm{m} 2 \mathrm{~K}$ and the free stream temperature amounting to $302.85 \mathrm{~K}$ (on the west wall). The height of the window was $1.2 \mathrm{~m}$ from the base of the room [10]. Fig. 1 shows the Smart Classroom modelling.

The position of the planned evaporator placement was as follows [11]. Fig. 2 shows Position 1 where the evaporator is placed on the west wall. Fig. 3 shows Position 2 where the evaporator is placed on the south wall. Fig. 4 shows Position 3 where the evaporator is placed on the north wall. Fig. 5 shows Position 4 where two evaporators are placed opposite to each other with one evaporator placed on the south wall and the other evaporator placed on the north wall.

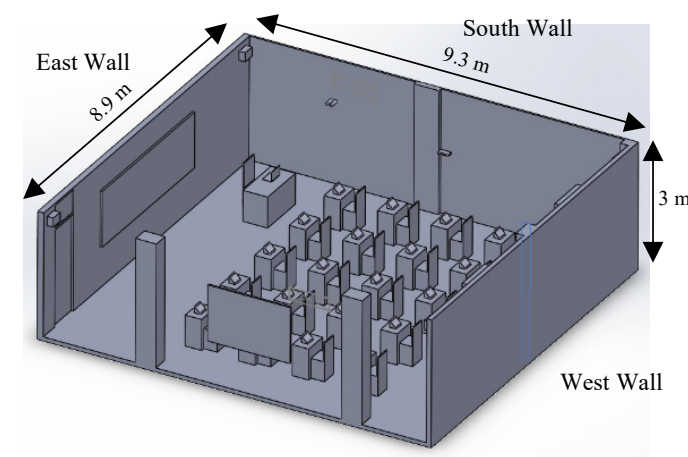

Fig. 1. Smart Classroom Model

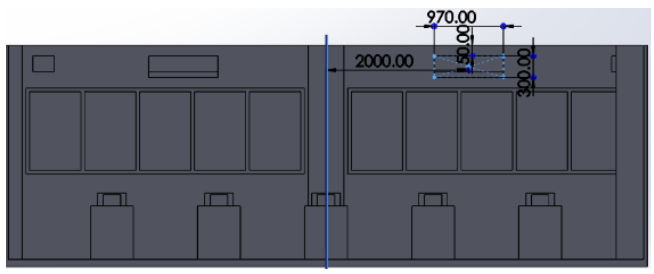

Fig. 2. Position 1

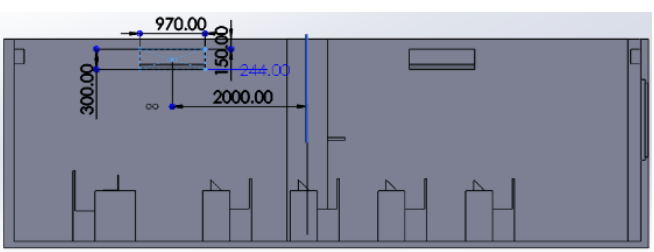

Fig. 3. Position 2

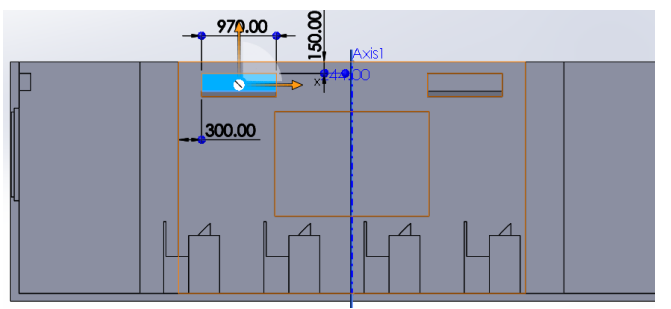

Fig. 4. Position 3

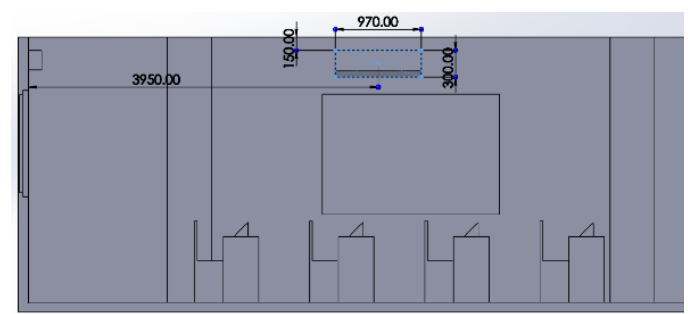

(a)

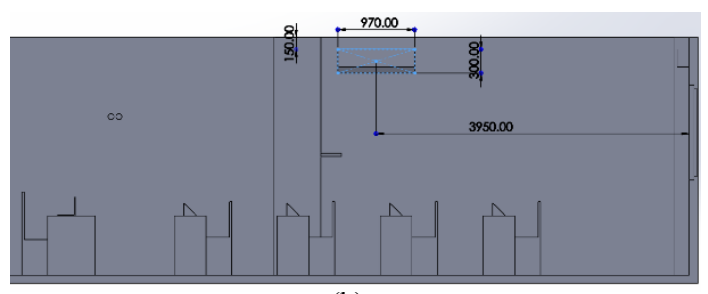

(b)

Fig. 5. Position 4, evaporator on (a) the north wall, and (b) the south wall 
Table 1 and Table 2 show the initial parameters and the initial air conditions of the simulations based on the literature parameter guidelines [5][12][13].

TABLE I. SIMULATION PARAMETERS

\begin{tabular}{|l|l|}
\hline \multicolumn{1}{|c|}{ Setup Menu } & \multicolumn{1}{c|}{ Value } \\
\hline Meshing & Automesh (Polyhedral) \\
\hline Gravity (On) & -9.81 \\
\hline Models & Energy Equation \\
\hline Viscous Model & K-Epsilon (2 Equation) \\
\hline Initialization & Standard \\
\hline \hline
\end{tabular}

TABLE II. INITIAL AIR CONDITION

\begin{tabular}{|l|l|}
\hline \multicolumn{1}{|c|}{ Setup Menu } & \multicolumn{1}{c|}{ Value } \\
\hline Outlet Temperature & $295 \mathrm{~K}$ \\
\hline Initial Temperature & $300 \mathrm{~K}$ \\
\hline$\rho$ or Density & $1.225 \mathrm{~kg} / \mathrm{m} 3$ \\
\hline Velocity & $4.6 \mathrm{~m} / \mathrm{s}$ \\
\hline$\eta$ or Absolute Viscousity & $1.79 \mathrm{E}-05 \mathrm{~N} . \mathrm{s} / \mathrm{m} 2$ \\
Ratio of Specific Heats & 1.4 \\
\hline \hline
\end{tabular}

The evaporator output airflow velocity data were measured at 27 points where there were 21 points at a $1.35-\mathrm{m}$ (the assumed height of a sitting person) and 6 points at a $1.65-\mathrm{m}$ height (the assumed height of a standing teacher), namely at points T2 T7. Fig. 6 Airflow velocity data measurement points (top view) and Fig. 7 Airflow velocity data measurement points (side view) show these points [5][8][14][15].

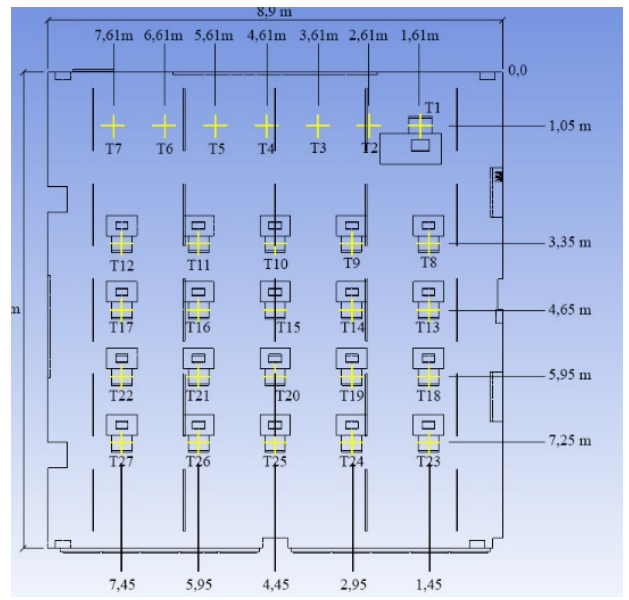

Fig. 6. Airflow velocity data measurement points (top view)

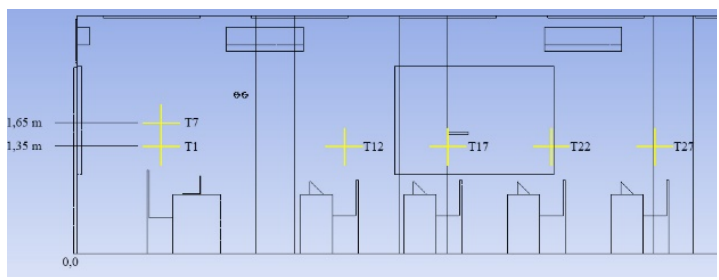

Fig. 7. Airflow velocity data measurement points (side view)

\section{RESUlT AND DisCUSSION}

\section{A. Result}

Fig. 8 Airflow patterns position (a) - (d) below show the simulation results of the airflow patterns of the four models of the planned evaporator placement positions. It was found out that each evaporator position produced a different airflow pattern.

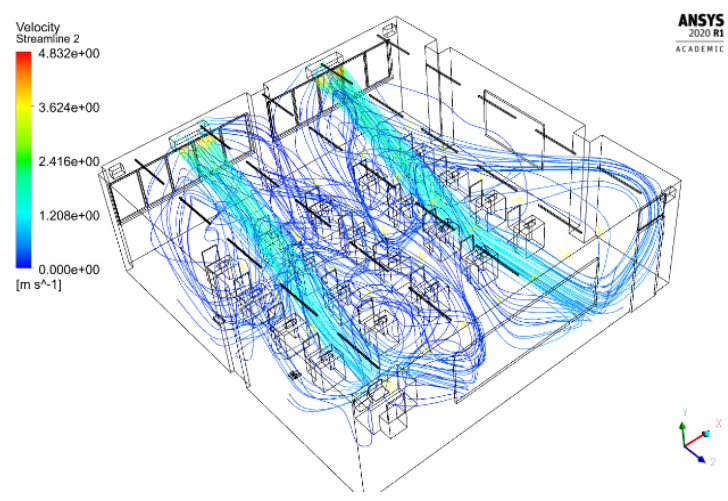

(a)

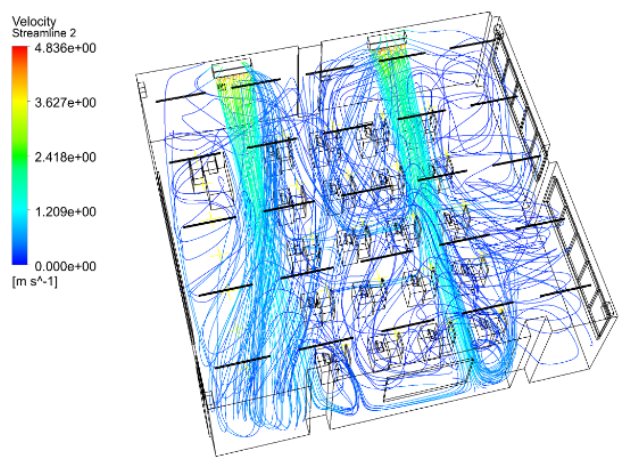

$\underset{2020 \mathrm{RI}}{\text { ANSYS }}$

(b)

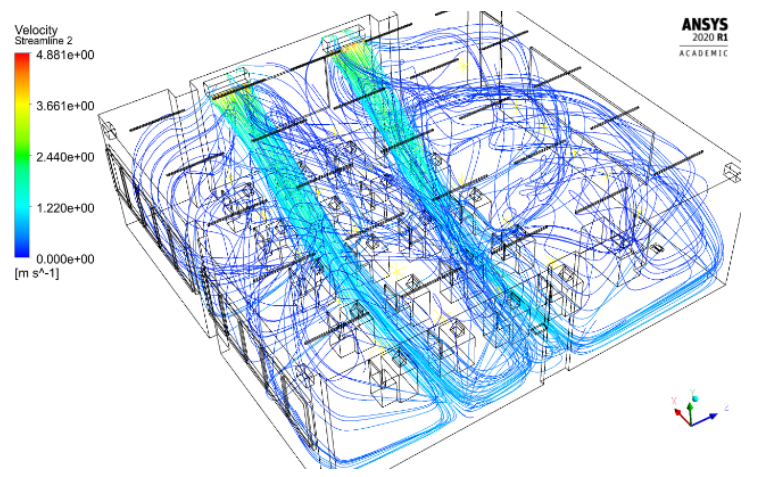

(c) 


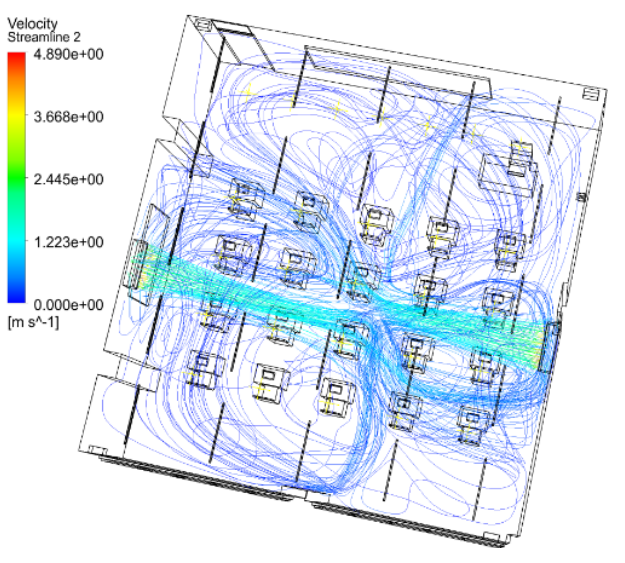

(d)

Fig. 8. Airflow patterns of (a) Position 1, (b) Position 2, (c) Position 3, and (d) Position 4

Fig. 9 Airflow velocity distribution at 1.35-m altitude (a) - (d) below show the results of the air velocity distribution of the evaporator output at a $1.35-\mathrm{m}$ altitude and the measurement point for the air flow velocity exceeding the limits recommended by SNI 03-6572-2001.

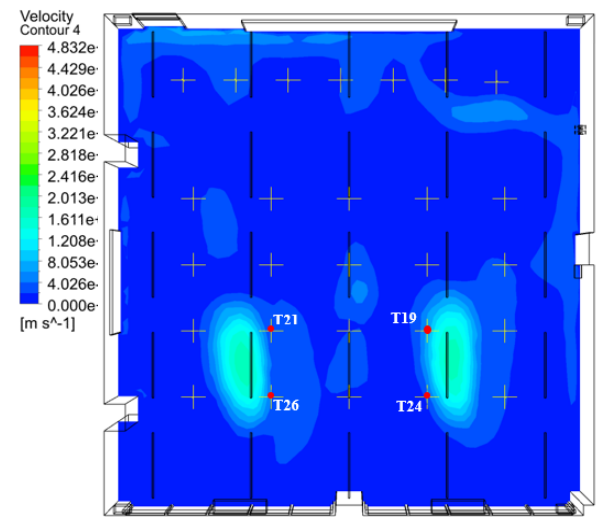

(a)

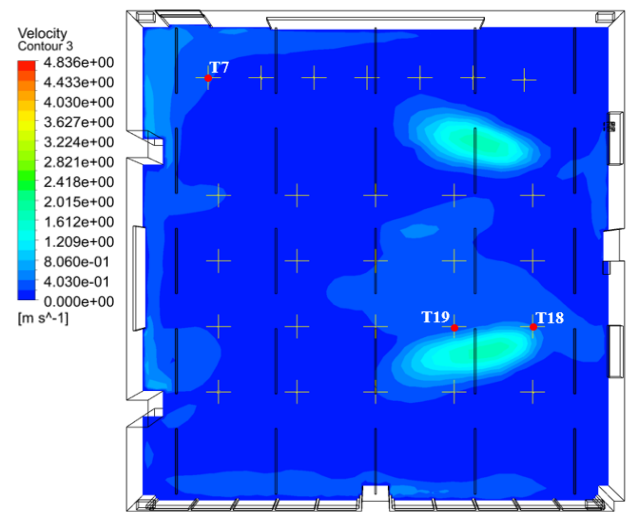

(b)

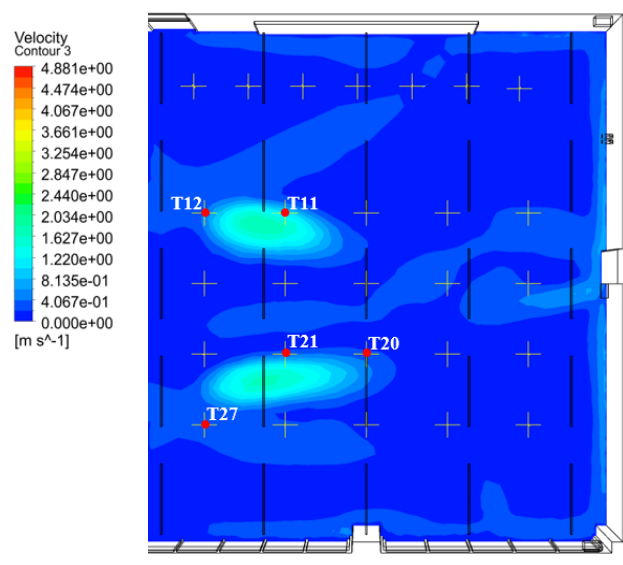

(c)

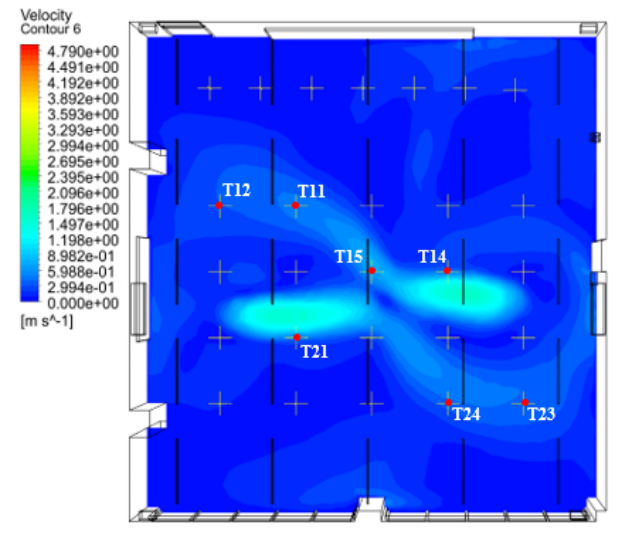

(d)

Fig. 9. Airflow velocity distribution at 1.35-m altitude for (a) Position 1, (b) Position 2, (c) Position 3, and (d) Position 4

The average room temperatures produced in the simulations were $24.27^{\circ} \mathrm{C}, 24.5^{\circ} \mathrm{C}, 24.45^{\circ} \mathrm{C}$, and $24.38^{\circ} \mathrm{C}$ for Position 1, Position 2, Position 3, and Position 4, respectively. Moreover, Fig. 10 Temperature distribution at a $1.35-\mathrm{m}$ altitude (a) - (d) below show the temperature distribution on the plane with a $1.35-\mathrm{m}$ height for each position of the evaporator placements.

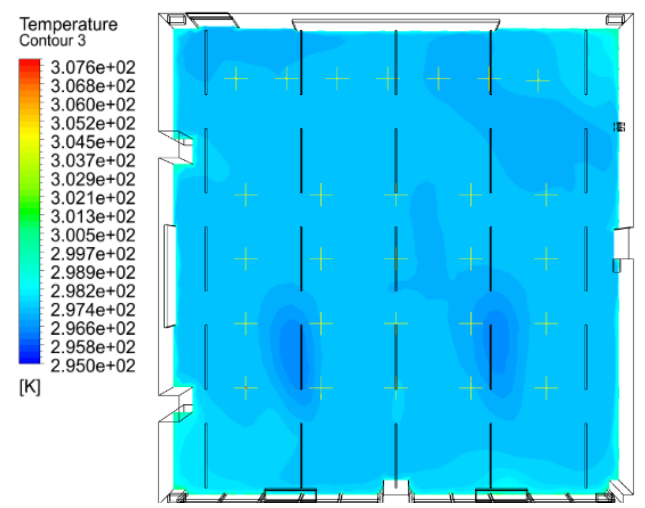

(a) 


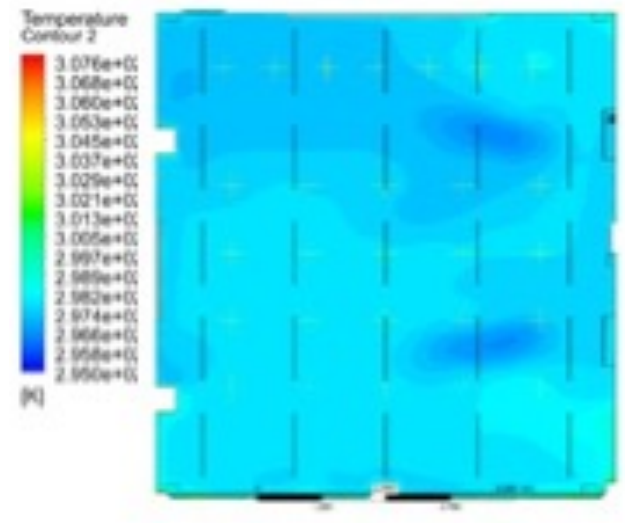

(b)

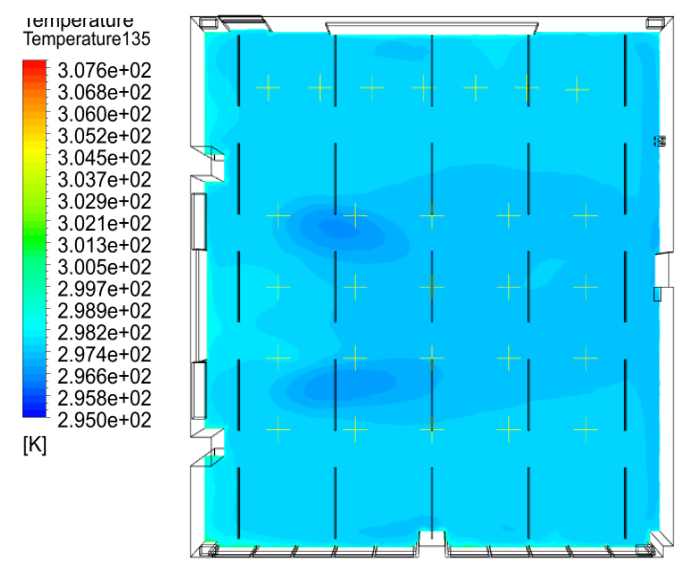

(c)

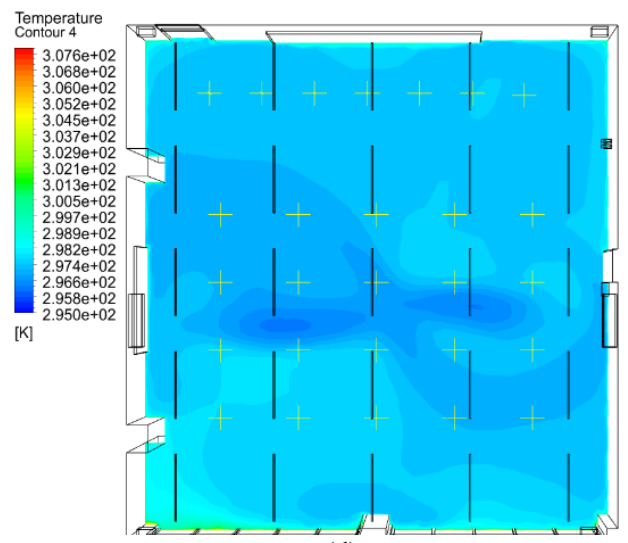

(d)

Fig. 10. Temperature distribution at a 1.35-m altitude (a) Position 1, (b) Position 2, (c) Position 3, and (d) Position 4

\section{B. Discussion}

Based on the results of the measurements of the CFD simulations, it was found out that in Position 1 there were 4 points exceeding the standard limit of the air velocity recommended by SNI 03-6572-2001; it exceeded $0.25 \mathrm{~m} / \mathrm{s}$ at points T19 $(0.673 \mathrm{~m} / \mathrm{s}), \mathrm{T} 21(0.282 \mathrm{~m} / \mathrm{s}), \mathrm{T} 24(0.317 \mathrm{~m} / \mathrm{s})$, and T26 $(0.367 \mathrm{~m} / \mathrm{s})$. In Position 2 , there were 3 points exceeding the standard limit namely at points T7 $(0.266 \mathrm{~m} / \mathrm{s}), \mathrm{T} 18(0.419$ $\mathrm{m} / \mathrm{s})$, and T19 $(0.286 \mathrm{~m} / \mathrm{s})$. In Position 3 there were 4 points exceeding the standard limit, namely at points T11 (1.084 $\mathrm{m} / \mathrm{s}), \mathrm{T} 12(0.422 \mathrm{~m} / \mathrm{s}), \mathrm{T} 20(0.268 \mathrm{~m} / \mathrm{s})$, and T21 $(0.384 \mathrm{~m} / \mathrm{s})$.
In Position 4 there were 7 points exceeding the standard limit, namely at points $\mathrm{T} 11(0.442 \mathrm{~m} / \mathrm{s}), \mathrm{T} 12(0.293 \mathrm{~m} / \mathrm{s}), \mathrm{T} 14(0.464$ $\mathrm{m} / \mathrm{s}), \mathrm{T} 15(0.648 \mathrm{~m} / \mathrm{s}), \mathrm{T} 21(0.504 \mathrm{~m} / \mathrm{s}), \mathrm{T} 23(0.381 \mathrm{~m} / \mathrm{s})$, and T24 $(0.353 \mathrm{~m} / \mathrm{s})$.

The ideal evaporator placement position would be determined based on the results of the average room temperature and the results of the air velocity at each of the measurement points complying with the standards recommended by SNI 03-6572-2001 in the case of the thermal comfort. Fig. 11 Comparison of the average room temperature at each evaporator position below shows the comparison of the results of the average room temperature.

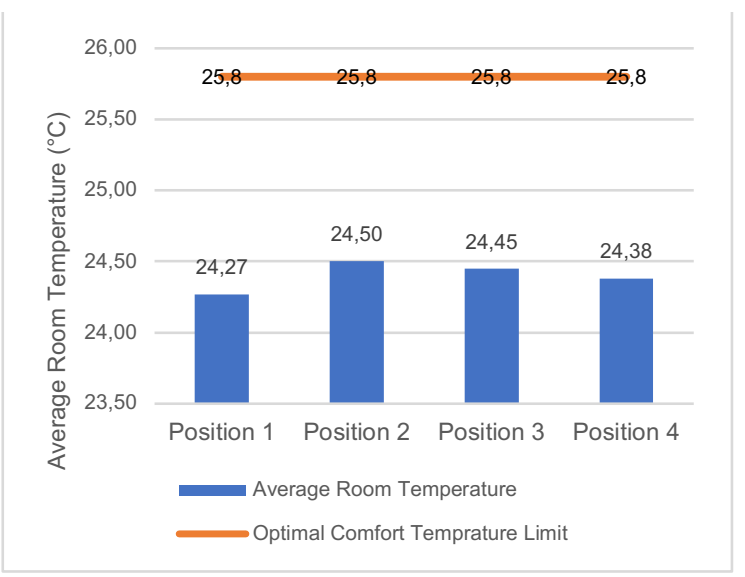

Fig. 11. Comparison of the average room temperature at each evaporator position

Fig. 12 Comparison of total measurement points that meets airflow velocity standards below shows the comparison of the total air flow velocity measurement points complying with the speed standards recommended by SNI 03-6572-2001.

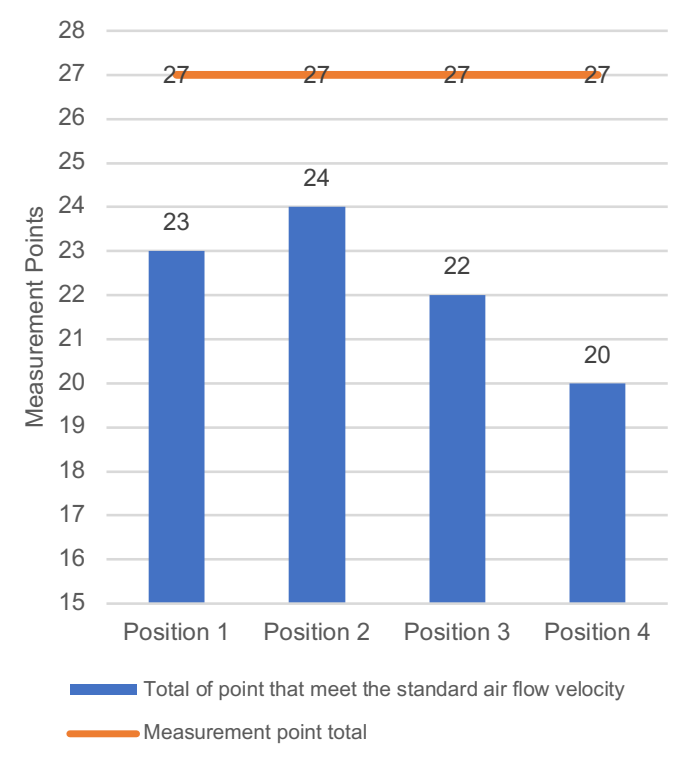

Fig. 12. Comparison of total measurement points that meets airflow velocity standards

Based on the comparison of the average room temperature simulation results as shown in Fig. 11 above, all the results of 
the average temperature of each of the simulated rooms did not exceed the comfortable temperature limit in terms of the optimal comfort category. Moreover, Position 2 or the position of the evaporator placed on the south wall constituted the largest number of the measurement points complying with the standard air flow velocity recommended by SNI 03-65722001, namely 24 points out of the total 27 measurement points.

\section{CONCLUSION}

Based on the results of the air flow simulations employing a CFD method made at each of the planned evaporator positions, it was found out that various airflow patterns were obtained at each planned position. Position 2 or the position of the evaporator placed on the south side of the wall was the most ideal position to place the evaporator since it met the comfortable temperature standards and there were 24 air flow velocity measurement points out of the total 27 measurement points complying with the standard recommended by SNI 03-6572-2001.

\section{ACKNOWLEDGEMENT}

We say thank you for supporting and funding Directorate of Resources Kemendikbud Ristek in accordance with the Research Contract for the Implementation of the Research Program Number 415/A/LPT/USAKTI/VII/2020

\section{REFERENCES}

[1] W. M. G. Alenazy, "Interactivity Oriented System Architecture for the 21 st Century Classroom: the New Smart Classroom," University of Technology, Australia, 2017

[2] Y. Shi, W. Qin, Y. Suo, and X. Xiao, Handbook of Ambient Intelligence and Smart Environments, no. June. 2010.
[3] B. Talarosha, "Menciptakan Kenyamanan Thermal Dalam Bangunan," J. Sist. Tek. Ind., vol. 6, no. 3, pp. 148-158, 2005.

[4] Y. P. Sholichin, "Universitas Indonesia Pengaruh Material Dinding Terhadap Nilai Ottv Pada Universitas Indonesia," Universitas Indonesia, 2012

[5] P. Bambang, "Analisis Kebutuhan Beban Pendingin dan Pengaruh Aliran Udara Pendingin Terhadap Temperatur Udara dalam Ruang Kantor," Universitas Trisakti, 2018.

[6] A. Sarinda, Sudarti, and Subiki, "Analisis Perubahan Suhu Ruangan Terhadap Kenyamanan Termal di Gedung 3 Fkip Universitas Jember," J. Pembelajaran Fis., vol. 6, no. 3, pp. 305-311, 2017.

[7] H. N. Yasmiraja, "Perencanaan dan Pemasangan Air Conditioning Pada Ruang Dosen dan Teknisi PSD III Teknik Mesin Universitas Diponegoro Semarang," Universitas Diponegoro, 2017.

[8] R. Azamuddin, "Analisis Distribusi Aliran Udara Pada Ruangan Dengan Variabel Temperatur dan Penempatan AC Menggunakan Metode Computational Fluid Dynamics (CFD)," Universitas Muhammadiyah Surakarta, 2017.

[9] BSN, "SNI - 03 - 6572 - 2001, Tata Cara Perancangan Sistem Ventilasi dan Pengkondisian Udara pada Bangunan Gedung," pp. 1-55, 2003, [Online]. Available: http://staffnew.uny.ac.id/upload /132100514/ pendidikan/perencanaan-pendingin.pdf.

[10] J. P. Holman, Heat Transfer, 10th ed. Avenue of the Americas, New York, NY 10020: The McGraw-Hill Companies, Inc, 2010.

[11] SHARP, "Cara Memasang AC dengan Benar," 2017. https://id.sharp/news/cara-memasang-ac-dengan-benar (accessed Jul. 20, 2020).

[12] A. Patel and P. S. Dhakar, "CFD Analysis of Air Conditioning in Room Using Ansys Fluent," vol. 5, no. 2, pp. 436-441, 2018, doi: 10.13140/RG.2.2.13462.50249.

[13] N. Damastuti and R. D. Nasihien, "Simulasi Kecepatan Angin dengan CFD Untuk Mengetahui Tingkat Kenyamanan Thermal Masjid Narotama II-1 II-2," vol. 9, no. November, pp. 1-4, 2017.

[14] Y. A. Sabtalistia, L. Mawardah, E. Poedjioetami, D. T. Arsitektur, I. Teknologi, and A. Tama, "Perbandingan Kenyamanan Termal dalam Ruangan Kantor yang Menggunakan Sistem Ceiling Air Conditioning (CAC), Floor Air Conditioning (FAC), dan Celing Fan," no. Snttm Xiii, pp. 15-16, 2014.

[15] E. Neufrt and S. Tjahjadi, Data Arsitek (BAUENTWURFLEIIRE), 1st ed. Jakarta: Erlangga, 1996. 